\title{
Increasing the energy efficiency of an enterprise by point compensating of power quality distortions
}

\author{
Egor Zamyatin ${ }^{1, *}$, Irina Voytyuk ${ }^{1}$ and Elena Zamyatina ${ }^{1}$ \\ ${ }^{1}$ Sant-Petersburg Mining University, St. Petersburg, Russian Federation
}

\begin{abstract}
The cost of any product includes the cost of electrical energy in its production. Enterprises use various methods to reduce the cost of electric energy. One of the most common methods is to reduce the loss of active power in the distribution network of an enterprise. This is achieved by compensating for distortions in the power quality of electrical energy using compensating devices. The method presented in the article offers point compensation of distortions in the power quality indicators of electric energy. Point connection of compensating devices allows their small number to be used. But, at the same time, a greater effect is achieved. The connection points of compensating devices are determined by the developed method. The method includes three stages: collecting data on consumers of electric energy at an enterprise and on the topology of the distribution electric network, analyzing the results obtained using the developed algorithm, and determining connection points using the Pareto method. Also, the developed method was compared with the classical ones according to the criterion of the ratio of implementation costs to the effect of its application.
\end{abstract}

\section{Introduction}

Currently, the share of electric power costs in the prime cost of production varies from $10 \%$ to $20 \%$ [1-3]. For example, in [2] the share of electric power costs makes $12-15 \%$, and in [1] it makes $16 \%$. The level of active power losses is directly associated with electric power quality [4-11]. In connection therewith, it is required to improve electric power quality, especially at enterprises with a high share of electric power costs in the prime cost of production. If the quality parameters of electric power fail to comply with normal values, additional active power losses occur [12-16]. Requirements for the quality parameters of electric power vary depending on the country. However, the parameters affecting additional active power losses remain unchanged [17]. According to the results of the analysis, it was found that [18-21] the following parameters primarily affect electric power losses:

- non-sinusoidality of the current or voltage curve;

- load power factor (reactive power).

However, the state standard of the Russian Federation does not standardize either the level of current harmonic distortions, or the level of reactive power, although it is these distortions that primarily increase active power losses, reducing the energy efficiency of an enterprise. There are many devices to improve electric power quality [5,22-24], as well as multiple variants of their connection. Having analyzed the methods for selecting the connection points of compensating devices [25-27], a new method based on the point connection of compensating devices directly at the load, which distorts electric power quality, was developed.

\section{Method}

The method is based on the following principle: each consumer contributes to the total active power losses. However, it is considered economically unviable to connect compensating devices for each consumer that distorts electric power quality parameters. Thus, first of all, it is necessary to determine the expression for assessing contribution to the total active power losses. Further, it is required to identify significant consumers that make the largest contribution to the total active power losses.

It is known that, in the general case, active power losses are determined by the expression:

$$
\Delta P=3 I^{2} R,
$$

where: $I$ is the module of the full load current in the line, $R$ is the active resistance of the line.

Then, expression (2) shows the dependence of active power losses, depending on the current of fundamental harmonic and the total harmonic distortion:

$$
\Delta P=3 I_{1}^{2}\left(1+T H D_{I}^{2}\right) R,
$$

where: $I_{1}$ is the module of the fundamental harmonic current, $T H D_{I}$ is the total harmonic distortion in current.

\footnotetext{
*Corresponding author: zamyatin_eo@pers.spmi.ru
} 
Thus, it can be concluded that the current curve nonsinusoidality significantly affects the value of active power losses. Non-sinusoidality of voltage does not directly affect active power losses, however, nonsinusoidality of voltage can result to the current curve sinusoidality distortion.

Reactive power and power factor are not standardized parameters of electric power quality. However, these parameters significantly affect power losses.

Power factor is the value reflecting the share of total power that has become active:

$$
P F=\frac{P}{S},
$$

where: $P$ is active power, $S$ is total power.

In the presence of reactive power in the network, losses during electric power transmission are determined by the expression:

$$
\Delta P=3\left(\frac{I_{A}}{P F}\right)^{2} R,
$$

where: $I_{A}$ is the active component of the current, $P F$ is the power factor.

It is apparent that, reactive power increases losses during electric power transmission, increasing the full load current in the line.

In order to determine the connection points of the compensating device, it is necessary to determine the contribution of consumers to the total active power losses and to rank them by the amount of contribution. The value of the total active power losses during electric power distribution is taken as the criterion for assessing the energy efficiency of the electro-technical complex of an enterprise.

Thus, in order to determine the contribution by an individual consumer, it is necessary to determine the dependence:

$$
Z\left(\frac{\Delta P_{i}}{\Delta P_{\Sigma}}\right)
$$

where: $Z$ is the function, reflecting the consumer's contribution to the total active power losses; $\Delta P_{i}$ active power losses in the electric power transmission line, through which only the $i$-th consumer's current passes; $\Delta P_{\Sigma}-$ total active power losses in the electrotechnical complex.

Meanwhile, it should be taken into account that the function $Z$ as a result of calculations will show only a quantitative characteristic, namely, which consumer affects losses to a greater extent and which one to a lesser extent.

Non-linear load distorts the current waveform. The effective value of the distorted current, via the value of the total coefficient of harmonic components, is determined by the expression:

$$
I=I_{1} \sqrt{\left(1+T H D_{I}^{2}\right)} .
$$

In view of the above, one can use the concept of distortion factor $-k$ :

$$
k=\sqrt{\left(1+T H D_{I}^{2}\right)}
$$

Expression (7) shows to what extent the current curve of a single load is distorted. If $k=1$ - there are no distortions, if $k>1$ - the current curve is distorted, it is also obvious that $k \geq 1$.

Further, it is proposed to assess the load nonlinearity using the distortion factor, since, according to the paper, a direct correlation between the total harmonic distortion in current and power losses was established (expression 2).

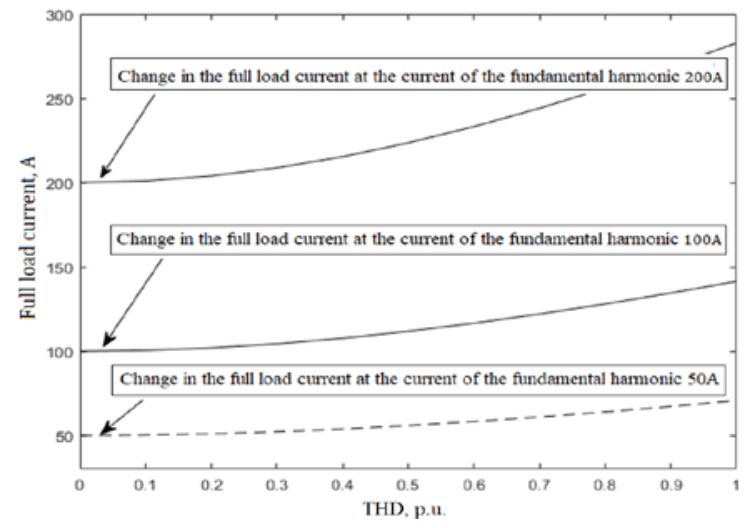

Fig. 1. Family of characteristics of the full load current when changing the current of the fundamental harmonic.

For example, figure 1 illustrates the dependences, obtained for currents with different effective values at the fundamental frequency, with a varying total harmonic distortion. As it follows from the obtained dependences, the full load current increases at the increase in $\mathrm{THD}_{\mathrm{I}}$. Hence it appears that when ranking the consumers, first of all, the distortion power factor in current should be taken into account.

It is obvious that active power losses in electric power transmission lines are directly proportional to the active resistance of electric power transmission lines. The active resistance of the conductor is determined by the known expression:

$$
R=\rho \frac{l}{S^{\prime}}
$$

where $\rho$ is the specific resistance of the conductor, Ohm $\frac{m m^{2}}{m} ; 1$ is the length of the conductor, $\mathrm{m} ; S^{\prime}$ is the cross-section of the conductor, $\mathrm{mm}^{2}$. 


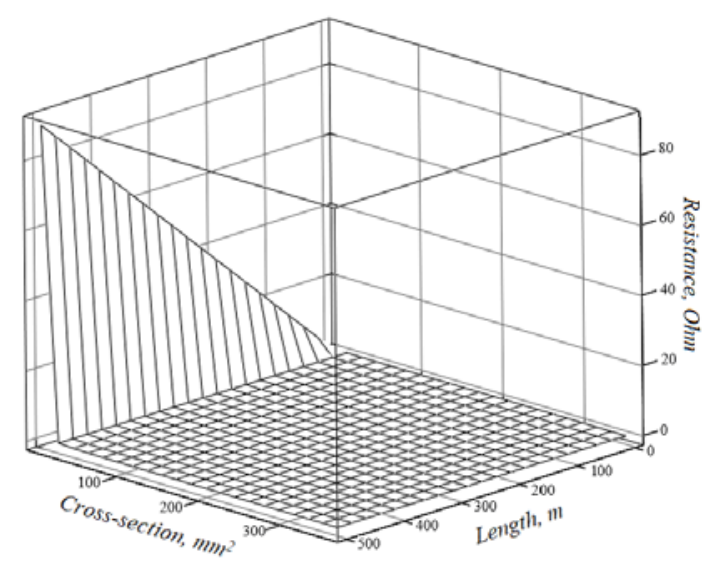

Fig. 2. The surface of the change in the value of active resistance when changing the length and cross-section of the conductor.

The dependence analysis, presented in figure 2, indicates that the resistance of the conductor increases sharply with the increase in cross-section and length, however this phenomenon occurs when the value of cross-section is close to zero. The analysis also revealed that the change in conductor's cross-section to a lesser extent affects the change in active resistance, than the change in its length.

Thus, taking the foregoing into account and assuming that the specific resistance of the material of wires at the electric power transmission lines is the same for one voltage level, we shall accept that the active resistance depends only on the conductor's length.

The total power module can be determined by the expression:

$$
S=U I,
$$

where: $U$ is the effective value of voltage, $I$ is the effective value of current.

Active load power is determined by the expression:

$$
P=U I \cdot P F,
$$

where: $P F$ is the power factor.

Reactive power, in the presence of distortions in the current or voltage waveform, is determined by the expression:

$$
Q=U I \sqrt{1-P F^{2}} \text {. }
$$

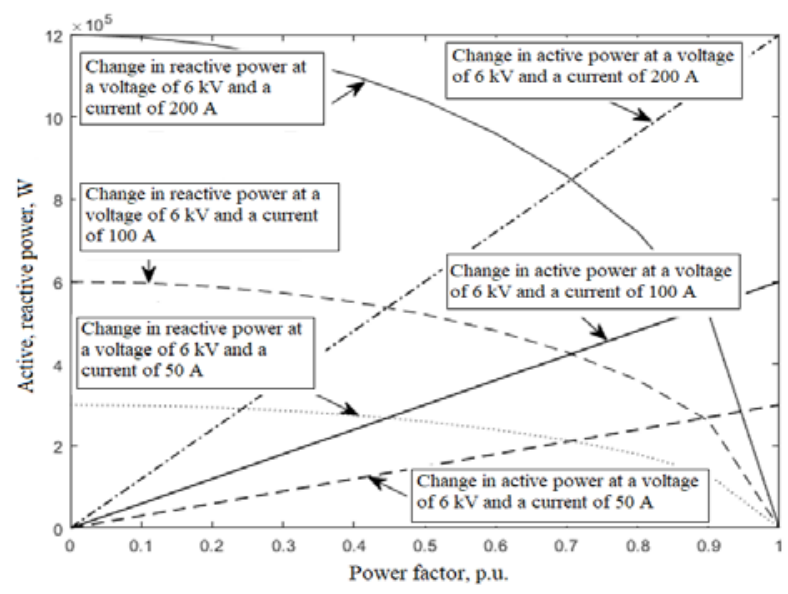

Fig. 3. Family of characteristics of active and reactive power when changing the power factor with specified values of current and voltage.

To rank consumers by their contribution to active power losses, it should be understood that, finally, the current in electric power transmission lines affects the losses. Therefore, to reduce the losses, it is necessary to reduce the current. The current is directly proportional to the total power, and the total power includes active and reactive components. The active component cannot be reduced. The reactive component can be reduced to zero (figure 3), by increasing the power factor.

Thus, when determining the contribution by consumers to active power losses, it is necessary to consider the consumer's active power as well as its power factor.

In view of the above, a number of assumptions were made for further research, namely:

- The specific resistance of wires at the electric power transmission line is the same;

- Cross-sections of electric power transmission line's conductors at one enterprise are assumed equal to each other;

- Voltage in the electro-technical complex of an enterprise is the same at all points.

Then the power losses can be represented as follows:

$$
\Delta P_{i}=3 \frac{\left(S_{i}^{2}-P_{i}^{2}\right) k_{i}^{2}}{U_{1}^{2} \sin \left(\varphi_{i}\right)} \rho \frac{l_{i}}{S^{\prime}{ }_{i}},
$$

where: $\Delta P_{i}$ - active power losses in the electric power transmission line, feeding the $i$-th consumer; $S_{i}$ is total power module of the $i$-th consumer; $P_{i}$ is active power of the $i$-th consumer; $\rho$ is the specific resistance of electric power transmission line of the $i$-th consumer; $S^{\prime}{ }_{i}$ is the cross-section of wires of the electric power transmission line of the $i$-th consumer; $k_{i}$ is the current distortion factor of the $i$-th consumer.

As mentioned above, the task is to determine the consumers that contribute most to the total active power losses, namely to determine the function $Z_{i}$ :

$$
Z_{i}=\frac{\Delta P_{i}}{\Delta P_{\Sigma}}=\frac{\left(S_{i}^{2}-P_{i}^{2}\right) k_{i}^{2} \rho l_{i} U_{1}^{2} \sin \left(\varphi_{\Sigma}\right) S_{\Sigma}^{\prime}}{U_{1}^{2} \sin \left(\varphi_{i}\right) S_{i}^{\prime}\left(S_{\Sigma}^{2}-P_{\Sigma}^{2}\right) k_{\Sigma}^{2} \rho l_{\Sigma}},
$$

where: $\Delta P_{\Sigma}$ - total active power losses in the electric power transmission line; $S_{\Sigma}$ is the module of the sum of the total power of consumers; $P_{\Sigma}$ is the total active power of consumers; $S_{\Sigma}{ }_{\Sigma}$ is the equivalent cross-section of wires of the electric power transmission line; c $k_{\Sigma}$ is the total current distortion factor.

By applying the above-mentioned assumptions we will get the expression:

$$
Z_{i}=\frac{l_{i}}{l_{\Sigma}} \frac{P_{i}^{2}}{P_{\Sigma}^{2}} \frac{P F_{\Sigma}^{2}}{P F_{i}^{2}} \frac{k_{i}^{2}}{k_{\Sigma}^{2}}
$$

where: $P F_{i}, P F_{\Sigma}$ are the $i$-th consumer's power factors and the weighted average, respectively. 
After determining the numerical values of the function $Z_{i}$ for each consumer, it is necessary to rank them in descending order of the obtained values. According to the Pareto principle (the solution vector $\bar{x}^{\prime} \in S$ is called Pareto-optimal if there is no $\bar{x} \in S$ such, that $f(\bar{x}) \leq f\left(\bar{x}^{\prime}\right)$ for all $i-1,2, \ldots, k$ and $f\left(\bar{x}^{\prime}\right)<f(\bar{x})$ for at least one $\left.i\right)$, it will be necessary to consider only those consumers that cause most active power losses.

\section{Results and Discussion}

As an example of the method implementation, simulation modeling of the distribution network of the medium voltage electro-technical complex, containing both linear and non-linear consumers of electric power, as shown in figure 4, was carried out.

According to this scheme, the method implementation is as follows. The source data are presented in table 1.

Table 1. The source data.

\begin{tabular}{|c|c|c|c|c|c|}
\hline $\begin{array}{c}\text { No } \\
\cdot\end{array}$ & $\begin{array}{c}\text { Consumer } \\
\text { name }\end{array}$ & $\begin{array}{c}\mathrm{P}, \\
\mathrm{M} \\
\mathrm{W}\end{array}$ & $\begin{array}{c}\text { PF, } \\
\text { p.u. }\end{array}$ & $\begin{array}{c}\text { Electric } \\
\text { power } \\
\text { transmissio } \\
\text { n line } \\
\text { length, km }\end{array}$ & $\begin{array}{c}\text { The total } \\
\text { coefficient } \\
\text { of harmonic } \\
\text { components } \\
\text {, p.u. }\end{array}$ \\
\hline 1 & $\begin{array}{c}\text { Worksho } \\
\text { p No.1 }\end{array}$ & 1 & $\begin{array}{c}0.7 \\
1\end{array}$ & 10 & 0 \\
\hline 2 & $\begin{array}{c}\text { Worksho } \\
\text { p No.2 }\end{array}$ & 2 & $\begin{array}{c}0.8 \\
9\end{array}$ & 5 & 0.07 \\
\hline 3 & $\begin{array}{c}\text { Worksho } \\
\text { p No.3 }\end{array}$ & 2,1 & $\begin{array}{c}0.7 \\
3\end{array}$ & 25 & 0.2 \\
\hline 4 & $\begin{array}{c}\text { Worksho } \\
\text { p No.4 }\end{array}$ & 1 & $\begin{array}{c}0.3 \\
2\end{array}$ & 10 & 0 \\
\hline 5 & $\begin{array}{c}\text { Worksho } \\
\text { p No.5 }\end{array}$ & 2 & $\begin{array}{c}0.6 \\
9\end{array}$ & 15 & 0 \\
\hline 6 & $\begin{array}{c}\text { Worksho } \\
\text { p No.6 }\end{array}$ & 2 & $\begin{array}{c}0.8 \\
9\end{array}$ & 17 & 0 \\
\hline
\end{tabular}

Simulation modeling was carried out via the Matlab mathematical computing system, the Simulink software package.

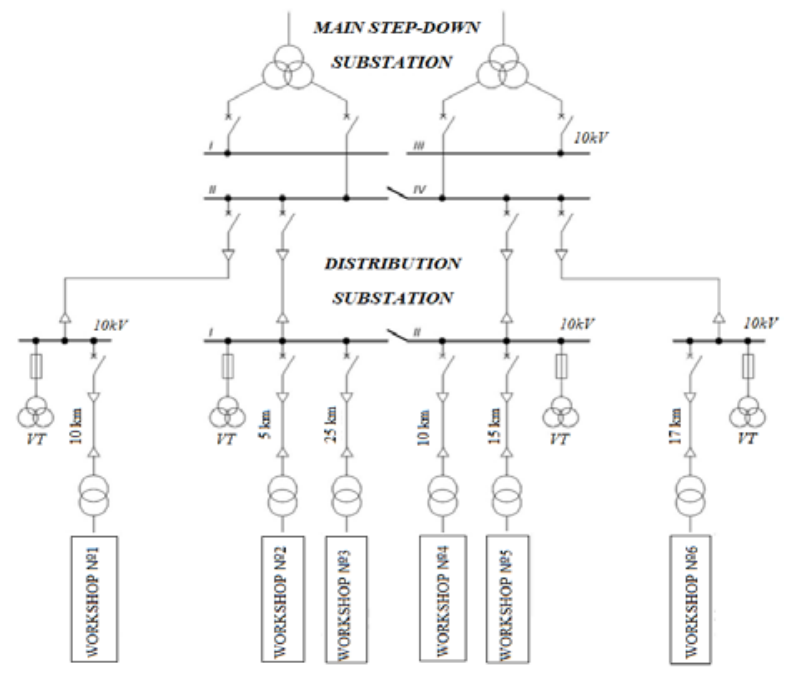

Fig. 4. Distribution electrical network of an enterprise
The simulation scheme, as shown in figure 5 is a single-phase equivalent circuit. High frequency harmonic distortions are simulated by current sources.

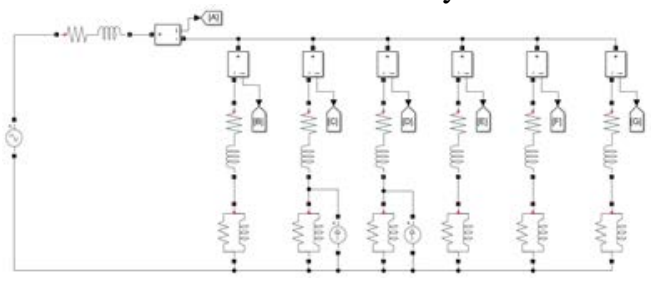

Fig. 5. Equivalent circuit for simulation

The result of simulation modeling is presented in table 2 .

Table 2. The result of simulation modeling.

\begin{tabular}{|l|l|l|l|}
\hline No. & Consumer name & Line current, A & $\begin{array}{l}\text { Active power } \\
\text { losses, kW }\end{array}$ \\
\hline 1 & Workshop No.1 & 130.6 & 17.1 \\
\hline 2 & Workshop No.2 & 211.1 & 22.3 \\
\hline 3 & Workshop No.3 & 276.1 & 190.6 \\
\hline 4 & Workshop No.4 & 272.7 & 74.4 \\
\hline 5 & Workshop No.5 & 246.8 & 91.4 \\
\hline 6 & Workshop No.6 & 198.1 & 66.7 \\
\hline 7 & Total losses & - & 462.4 \\
\hline
\end{tabular}

To determine the connection points, according to the proposed method, the data from table 1 are entered into a program that implements the algorithm for determining the connection points of compensating devices [28], with the result being a histogram (Fig. 6).

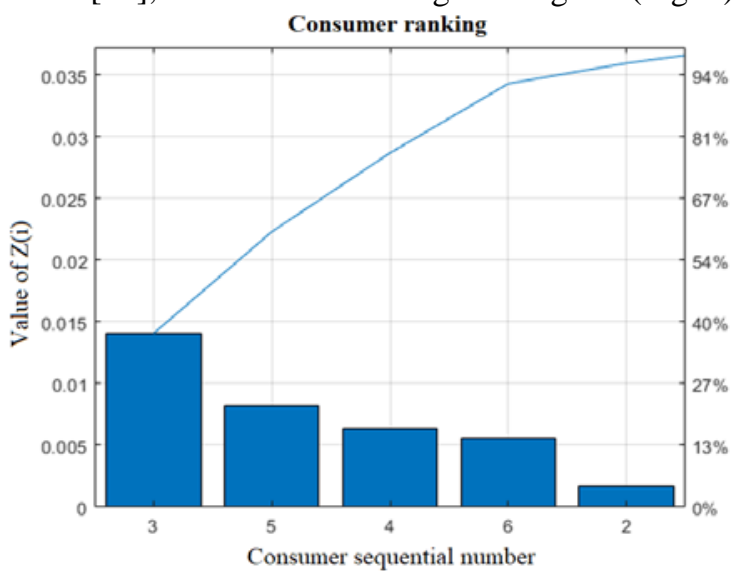

Fig. 6. Ranked consumers by contribution to total active power losses

The histogram shows that, the largest contribution to the total active power losses is made by consumers Nos. $3,5,4,6$. However, according to the proposed method, compensating devices must be connected to $80 \%$ of consumers. Thus, by compensating for the distortions created by consumers Nos. 3, 5, 4, the total active power losses will reduce to the optimal level (Table 3).

Table 3. The result of compensating for distortions according to the proposed method.

\begin{tabular}{|l|l|l|l|}
\hline No. & Consumer name & Line current, A & $\begin{array}{l}\text { Active power } \\
\text { losses, kW }\end{array}$ \\
\hline 1 & Workshop No.1 & 132.8 & 17.6 \\
\hline 2 & Workshop No.2 & 214.9 & 23.1 \\
\hline
\end{tabular}




\begin{tabular}{|l|l|l|l|}
\hline No. & Consumer name & Line current, A & $\begin{array}{l}\text { Active power } \\
\text { losses, kW }\end{array}$ \\
\hline 3 & Workshop No.3 & 193 & 93.1 \\
\hline 4 & Workshop No.4 & 96.9 & 9.4 \\
\hline 5 & Workshop No.5 & 189.4 & 53.8 \\
\hline 6 & Workshop No.6 & 201.4 & 69.0 \\
\hline 7 & Total losses & - & 266 \\
\hline
\end{tabular}

Comparison with other possible options for connecting compensating devices is presented in table 4.

Table 4. Comparison of the results of the use of compensating devices in different ways.

\begin{tabular}{|c|c|c|c|c|c|}
\hline No. & $\begin{array}{l}\text { Cons } \\
\text { umer } \\
\text { name }\end{array}$ & $\begin{array}{c}\Delta P \\
\text { without } \\
\text { compen } \\
\text { sation, } \\
\text { kW }\end{array}$ & $\begin{array}{c}\Delta P \\
\text { with } \\
\text { compens } \\
\text { ation } \\
\text { accordin } \\
\text { g to the } \\
\text { proposed } \\
\text { method, } \\
\mathrm{kW}\end{array}$ & $\begin{array}{c}\Delta P \\
\text { with } \\
\text { compen } \\
\text { sation } \\
\text { for all } \\
\text { distortio } \\
\mathrm{ns}, \mathrm{kW}\end{array}$ & $\begin{array}{c}\Delta P \\
\text { with } \\
\text { centralize } \\
\mathrm{d} \\
\text { compensat } \\
\text { ion, } \mathrm{kW}\end{array}$ \\
\hline 1 & $\begin{array}{l}\text { Work } \\
\text { shop } \\
\text { No.1 }\end{array}$ & 17.1 & 17.6 & 9.5492 & 18.1172 \\
\hline 2 & $\begin{array}{l}\text { Work } \\
\text { shop } \\
\text { No.2 }\end{array}$ & 22.3 & 23.1 & 19.0906 & 23.6096 \\
\hline 3 & $\begin{array}{l}\text { Work } \\
\text { shop } \\
\text { No.3 }\end{array}$ & 190.6 & 93.1 & 94.6729 & 138.651 \\
\hline 4 & $\begin{array}{l}\text { Work } \\
\text { shop } \\
\text { No.4 }\end{array}$ & 74.4 & 9.4 & 9.5492 & 79.0734 \\
\hline 5 & $\begin{array}{l}\text { Work } \\
\text { shop } \\
\text { No.5 }\end{array}$ & 91.4 & 53.8 & 54.6642 & 97.1554 \\
\hline 6 & $\begin{array}{l}\text { Work } \\
\text { shop } \\
\text { No.6 }\end{array}$ & 66.7 & 69.0 & 61.37 & 70.886 \\
\hline 7 & $\begin{array}{c}\text { Total } \\
\text { losse } \\
\mathrm{s} \\
\end{array}$ & 462.4 & 266.0 & 248.896 & 427.492 \\
\hline 8 & $\begin{array}{c}\Delta P \\
\text { reduc } \\
\text { tion, } \\
\%\end{array}$ & 0 & 42.5 & 46.2 & 7.5 \\
\hline
\end{tabular}

From the analysis of the data in table 4 it follows that the greatest effect in the form of reducing active power losses is achieved when connecting compensating devices directly to each consumer. The effect, according to the proposed method, is not significantly lower - $42.5 \%$ versus $46.2 \%$, the difference is less than $4 \%$, wherein the difference in the cost of compensating devices is more than $50 \%$, since only three compensating devices, instead of six, must be connected. The centralized compensation method showed the worst result, only $7.5 \%$, consequently, the enterprise that uses this method fails to eliminate distortions in its distribution network, therefore the use of this method is recognized as economically unviable.

\section{Conclusion}

The paper presents a new approach to the selection of connection points for compensating devices and their power, which allows to reduce active power losses in the distribution network of the enterprise's electrotechnical complex, in the process load of which nonlinear electric power receivers are widely used.

The proposed method is based on the function of consumer ranking, being introduced for the first time, wherein it is possible to determine those consumers that make the largest contribution to power losses in the enterprise's electric network in the presence of distortions in current and voltage.

It is shown that, using the Pareto principle, with the ranking function accounted for, it is possible to determine the optimal power level of compensating devices and place of their connection, ensuring power losses reduction at minimum cost.

Simulation modeling was carried out via the Matlab mathematical computing system, the Simulink software package, ensuring reliability of the obtained results. The proposed method allows one, with sufficient accuracy and low computational load, to identify consumers that make the largest contribution to the total active power losses, considering their impact on quality parameters and network topology.

\section{References}

1. S. A. Hatirli, B. Ozkan, and C. Fert, Renew. Energy 31, 427 (2006)

2. N. A. Madlool, R. Saidur, M. S. Hossain, and N. A. Rahim, Renew. Sustain. Energy Rev. 15, 2042 (2011)

3. M. Coroiu, in 2019 8th Int. Conf. Mod. Power Syst. (IEEE, 2019), pp. 1-8

4. T. T. Nguyen and A. V. Truong, Int. J. Electr. Power Energy Syst. 68, 233 (2015)

5. J. Wang, N. Zhou, Y. Ran, and Q. Wang, IEEE Trans. Smart Grid 10, 5360 (2018)

6. S. S. Halve, A. Koshti, and R. Arya, in 2019 3rd Int. Conf. Electron. Commun. Aerosp. Technol. (IEEE, 2019), pp. 1185-1189

7. Dr.K.Lenin, Int. J. Res. 6, 155 (2018)

8. I. Murashov, V. Frolov, M. Korotkikh, and L. Ushomirskaya, in MATEC Web Conf. (2018)

9. I. Murashov, V. Frolov, and D. Ivanov, in Proc. 2016 IEEE North West Russ. Sect. Young Res. Electr. Electron. Eng. Conf. EIConRusNW 2016 (2016), pp. 625-628

10. A. $\mathrm{Wu}$ and $\mathrm{B}$. Ni, Line Loss Analysis and Calculation of Electric Power Systems (2015)

11. D. Kumar and F. Zare, IEEE J. Emerg. Sel. Top. Power Electron. 4, 70 (2016)

12. A. V. Krasnozhon, R. O. Buinyi, and I. V. Pentegov, Tech. Electrodyn. 2016, 23 (2016)

13. V. Z. Manusov, U. Bumtsend, and E. S. Tretyakova, in Proc. - 2016 11th Int. Forum Strateg. Technol. IFOST 2016 (IEEE, 2017), pp. 
276-279

14. A. T. Bakesheva, T. I. Irgibaev, and A. E. Belousov, NEWS Natl. Acad. Sci. Repub. Kazakhstan 3, 114 (2019)

15. A. E. Belousov, G. K. Samigullin, and A. V. Kleimenov, Chem. Pet. Eng. 54, 392 (2018)

16. I. U. V. Murashov, V. Y. A. Frolov, D. Uhrlandt, S. Gortschakow, D. V. Ivanov, and A. D. Sivaev, in 22nd Symp. Phys. Switch. Arc (2017), pp. 124-128

17. A. N. Skamyin and V. S. Dobush, in IOP Conf. Ser. Earth Environ. Sci. (2018)

18. A. Toropchin, V. Frolov, and D. Uhrlandt, in 20th Symp. Phys. Switch. Arc 2013, FSO 2013 (2013), pp. 301-304

19. J. Sobota, V. I. Malarev, and A. V. Kopteva, J. Min. Inst. 238, 443 (2019)

20. D. Chavez, S. Espinosa, and D. Arias Cazco, IEEE Lat. Am. Trans. 14, 4540 (2016)

21. A. Pennycott, L. De Novellis, P. Gruber, and A. Sorniotti, Int. J. Veh. Des. 67, 157 (2015)

22. S. Mukherjee, A. Ganguly, A. K. Paul, and A. Kumar Datta, in 2018 Int. Conf. Comput. Power Commun. Technol. GUCON 2018 (IEEE, 2019), pp. 207-211

23. A. N. Skamyin and M. S. Kovalchuk, in Proc. 2018 IEEE Conf. Russ. Young Res. Electr. Electron. Eng. ElConRus 2018 (2018), pp. 780-783

24. L. Kuru, A. Ozturk, E. Kuru, and S. Cobanli, Teh. Vjesn. 23, 491 (2016)

25. H. G. Beleiu, I. N. Beleiu, S. G. Pavel, and C. P. Darab, Sustain. 10, (2018)

26. Z. Zeng, H. Yang, S. Tang, and R. Zhao, IEEE Trans. Power Electron. 30, 1255 (2015)

27. P. Thirumoorthi and N. Yadaiah, Simul. Model. Pract. Theory 52, 78 (2015)

28. E. O. Zamyatin, A. A. Belsky, and E. N. Zamyatina, The program for determining significant consumers when compensating for distortions in the quality parameters of electric energy No. 2019612546 (2019) 